\title{
Influence of dietary fish proteins on plasma and liver cholesterol concentrations in rats
}

\author{
BY XIZHONG ZHANG ${ }^{1,2}$ AND ANTON C. BEYNEN ${ }^{1,3}$ \\ ${ }^{1}$ Department of Laboratory Animal Science, State University, PO Box 80.166, 3508 TD Utrecht, \\ The Netherlands \\ ${ }^{2}$ Department of Nutrition and Food Hygiene, Shanxi Medical College, Taiyuan, Shanxi, \\ The People's Republic of China \\ ${ }^{3}$ Department of Human Nutrition, Agricultural University, PO Box 8129, 6700 EV Wageningen, \\ The Netherlands
}

(Received 7 April 1992 - Accepted 22 July 1992)

\begin{abstract}
The effects of amount and type of dietary fish proteins on plasma and liver cholesterol concentrations were evaluated in female rats. The isonitrogenous diets used contained $10 \mathrm{~g}$ cholesterol $/ \mathrm{kg}$ and were carefully balanced for residual fat, cholesterol, $\mathrm{Ca}, \mathrm{Mg}$ and $\mathrm{P}$ in the protein preparations. Cod meal, soya-bean protein or casein was incorporated into the diets as the only source of dietary protein at three levels: either 24,48 or $72 \mathrm{~g} \mathrm{~N} / \mathrm{kg}$ diet. Extra protein was added to the diet at the expense of the glucose component. In a second experiment soya-bean protein, casein, cod meal, whiting meal or plaice meal was added to the diet at a level of $24 \mathrm{~g} \mathrm{~N} / \mathrm{kg}$. When compared with casein, cod meal and soya-bean protein decreased plasma and liver cholesterol concentrations. A further cholesterol-lowering effect was achieved by increasing the proportion of either soya-bean protein or cod meal in the diet. Substitution of casein for glucose did not influence plasma and liver cholesterol concentrations. Plaice meal in the diet produced lower group mean plasma cholesterol concentrations than did whiting meal. In rats fed on the diet containing plaice meal, liver cholesterol concentrations were significantly lower than those in their counterparts fed on either cod meal or whiting meal. The present study demonstrates that different fish proteins in the diet have different effects on cholesterol metabolism and that the cholesterol-influencing properties of cod meal can be enhanced by the incorporation of higher proportions of this protein in the diet.
\end{abstract}

Protein intake: Fish proteins: Plasma cholesterol: Rat

The nature of dietary protein can influence cholesterol metabolism in experimental animals and humans (Kritchevsky, 1979; Carroll, 1982; Beynen, 1990). Most studies have focussed on the hypercholesterolaemic effect of casein $v$. soya-bean protein. In general, animal proteins are considered to be hypercholesterolaemic when compared with plant proteins (Carroll, 1981). This concept is based on the comparison of a limited number of proteins. For instance, little is known about the effects of various types of fish proteins. Moreover, as to the effects of dietary fish protein on serum cholesterol, controversial results have been reported (Peifer et al. 1961; Kritchevsky et al. 1982; Goulding et al. 1983; Wexler, 1983; Sugano et al. 1984; Iritani et al. 1985; Jacques et al. 1986, 1987; Bergeron \& Jacques, 1989). The different experimental results may relate to the use of poorly characterized fish proteins and experimental diets that were not balanced for components other than protein in the fish-protein preparations (Zhang \& Beynen, 1990). In the present experiments using rats fed on carefully balanced diets, the effects of cod, whiting and plaice meals on serum and liver 
cholesterol concentrations were determined. Dietary casein and soya-bean-protein isolate were used as reference proteins.

\section{MATERIALS AND METHODS}

\section{Diets}

Cod meal (Institute for Fishery Products, CIVO-TNO, Ijmuiden, The Netherlands), whiting and plaice fillet (local fish shop), casein (Havero BV, Rotterdam, The Netherlands) and soya-bean-protein isolate (Ralston Purina Co., St Louis, MO, USA) were used. The fillets of whiting and plaice were cut into small pieces, freeze-dried and powdered. The protein preparations were analysed for $\mathrm{N}$, cholesterol, fat, $\mathrm{Ca}, \mathrm{Mg}$ and $\mathrm{P}$. The results are given in Table 1. The amino acid compositions of the protein preparations are shown in Table 2. The fish proteins and casein had higher levels of lysine and methionine but lower levels of arginine, when compared with soya-bean protein. On the other hand, when compared with casein, both fish proteins and soya-bean protein had higher levels of cysteine and glycine.

In Expt. 1 both type and concentration of protein preparation in the diets were varied; soya-bean protein, casein and cod meal were used at three levels of $\mathrm{N}(24,48$ and $72 \mathrm{~g} / \mathrm{kg}$ diet). Extra protein was added to the diets at the expense of the glucose component. Expt 2 involved variation in the type of dietary protein only; soya-bean protein, casein, cod meal, whiting meal and plaice meal were compared at a fixed $\mathrm{N}$ concentration of $24 \mathrm{~g} / \mathrm{kg}$ diet. The experimental diets were balanced for $\mathrm{N}$, cholesterol, the amount and type of fat, $\mathrm{Ca}, \mathrm{Mg}$ and $\mathrm{P}$. Table 3 shows the ingredient composition of the diets. The analysed composition of the diets is given in Table 4 which indicates that the diets were reasonably well balanced. This is supported by the analysed fatty acid composition of the diets (Table 5). Separate batches of diet were made for each experiment. The diets were in meal form and kept at $4^{\circ}$ until feeding.

\section{Animals and experimental procedures}

The interval between the two experiments was about 2 months. Female Wistar rats ( $\mathrm{Cpb} / \mathrm{Hsd}$; Harlan-CPB, Zeist, The Netherlands) were used throughout. On arrival, when they were aged 3 (Expt 2) or 4 (Expt 1) weeks, the animals were housed, four in a Macrolon type III cage (UNO BV, Zevenaar, The Netherlands), with a layer of sawdust as bedding. The rats were fed $a d$ lib. on a commercial, pelleted natural-ingredient diet (RMH-B ${ }^{\circledR}$; Hope Farms, Woerden, The Netherlands) and tap water for $3 \mathrm{~d}$. Then they were transferred to the pre-experimental, purified diet containing soya-bean protein at a level of $24 \mathrm{~g} \mathrm{~N} / \mathrm{kg}$ (Table 3) and demineralized water. After 1 week (day 0 of the experimental period) the rats were divided into either nine (Expt 1) or five groups (Expt 2), each comprising six rats. The groups within each experiment had similar distributions of plasma cholesterol concentration and body weight. Each group was randomly assigned to one of the experimental diets. One group remained on the pre-experimental diet. Feed and demineralized water were provided $a d$ lib. The animals were weighed weekly, and feed intakes were recorded. Both experiments lasted 3 weeks.

During the experiment (days 0-21) the rats were housed individually in metabolism cages (Techniplast Gazzada, Buguggiate, Italy). The cages were placed in a room with controlled temperature $\left(20-24^{\circ}\right)$, relative humidity $(40-45 \%)$ and lighting (light, 06.00-18.00 hours).

Heparinized blood samples were taken in the non-fasting state by orbital puncture while under light diethyl ether anaesthesia. At the end of each experiment the anaesthetized animals were killed by cervical dislocation. Livers were removed and weighed; they were stored at $-20^{\circ}$ until analysis. 
Table 1. Analysed composition of the protein preparations

\begin{tabular}{lccccc}
\hline Type of protein... & $\begin{array}{c}\text { Soya-bean } \\
\text { protein }\end{array}$ & Casein & $\begin{array}{c}\text { Cod } \\
\text { meal }\end{array}$ & $\begin{array}{c}\text { Whiting } \\
\text { meal }\end{array}$ & $\begin{array}{c}\text { Plaice } \\
\text { meal }\end{array}$ \\
\hline Component (g/kg protein preparation) & & & & & \\
$\mathrm{N}$ & 134 & 141 & 130 & 147 & 146 \\
Crude fat & 53 & 17 & 46 & 46 & 45 \\
Cholesterol & $0 \cdot 00$ & $0 \cdot 26$ & $7 \cdot 15$ & $3 \cdot 43$ & $2 \cdot 66$ \\
$\mathrm{Ca}$ & $2 \cdot 8$ & $0 \cdot 7$ & $9 \cdot 6$ & $1 \cdot 7$ & $3 \cdot 0$ \\
$\mathrm{Mg}$ & $0 \cdot 7$ & $0 \cdot 1$ & $1 \cdot 1$ & $1 \cdot 4$ & $1 \cdot 3$ \\
$\mathrm{P}$ & $7 \cdot 9$ & $2 \cdot 2$ & $10 \cdot 0$ & $2 \cdot 0$ & $10 \cdot 5$ \\
\hline
\end{tabular}

Table 2. Amino acid composition of the protein preparations

\begin{tabular}{lcrrrr}
\hline \hline Type of protein... & $\begin{array}{c}\text { Soya-bean } \\
\text { protein }\end{array}$ & Casein & $\begin{array}{c}\text { Cod } \\
\text { meal }\end{array}$ & $\begin{array}{r}\text { Whiting } \\
\text { meal }\end{array}$ & $\begin{array}{c}\text { Plaice } \\
\text { meal }\end{array}$ \\
\hline Amino acid (g/kg protein preparation) & & & & & \\
Alanine & $35 \cdot 5$ & $28 \cdot 4$ & $47 \cdot 0$ & $52 \cdot 5$ & $51 \cdot 0$ \\
Arginine & $66 \cdot 0$ & $33 \cdot 5$ & $54 \cdot 0$ & $58 \cdot 0$ & $56 \cdot 0$ \\
Aspartate & $97 \cdot 5$ & $66 \cdot 0$ & $82 \cdot 5$ & $89 \cdot 0$ & $88 \cdot 5$ \\
Cysteine & $10 \cdot 3$ & $4 \cdot 5$ & $8 \cdot 3$ & $9 \cdot 0$ & $9 \cdot 8$ \\
Glutamine & $165 \cdot 5$ & $205 \cdot 0$ & $126 \cdot 0$ & $139 \cdot 0$ & $133 \cdot 5$ \\
Glycine & $34 \cdot 5$ & $16 \cdot 9$ & $41 \cdot 5$ & $47 \cdot 0$ & $46 \cdot 0$ \\
Isoleucine & $43 \cdot 0$ & $49 \cdot 5$ & $39 \cdot 5$ & $41 \cdot 5$ & $42 \cdot 0$ \\
Leucine & $69 \cdot 5$ & $88 \cdot 5$ & $64 \cdot 0$ & $69 \cdot 0$ & $68 \cdot 0$ \\
Lysine & $53 \cdot 5$ & $74 \cdot 5$ & $72 \cdot 5$ & $81 \cdot 5$ & $80 \cdot 5$ \\
Methionine & $11 \cdot 4$ & $25 \cdot 7$ & $26 \cdot 3$ & $27 \cdot 5$ & $26 \cdot 3$ \\
Serine & $47 \cdot 0$ & $56 \cdot 0$ & $40 \cdot 5$ & $41 \cdot 5$ & $41 \cdot 0$ \\
Threonine & $32 \cdot 5$ & $40 \cdot 5$ & $38 \cdot 0$ & $39 \cdot 5$ & $39 \cdot 5$ \\
Valine & $45 \cdot 0$ & $65 \cdot 0$ & $45 \cdot 0$ & $45 \cdot 5$ & $45 \cdot 5$ \\
\hline \hline
\end{tabular}

\section{Chemical analyses}

Crude protein $(\mathrm{N} \times 6.25)$ contents of protein preparations and diets were analysed by the Kjeldahl method (Joslyn, 1970). Cholesterol was determined by gas-liquid chromatography (Nordby \& Nagy, 1973). Crude fat was determined by the Soxhlet method (Joslyn, 1970) and fatty acid composition according to Metcalfe et al. (1966). Amino acids in the protein preparations were analysed by the method of Moore (1963) as modified by Slump \& Bos (1985). $\mathrm{Ca}$ and $\mathrm{Mg}$ in protein preparations and diets were analysed as described by Hoek et al. (1988). P was analysed by the method of Taussky \& Shorr (1953) in Expt 1, and with the use of the kit (MA-kit Phosphate) from F. Hoffmann-La Roche Co. Ltd Diagnostica (Basel, Switzerland) in Expt 2.

The concentrations of plasma cholesterol and triacylglycerols were measured enzymically using the kits (Monotest and Test-Combination) supplied by Boehringer Mannheim Gmbh (Mannheim, Germany). Control sera (Precinorm U and LIPIDS) from Boehringer Mannheim Gmbh were used as standards. Liver cholesterol was extracted and analysed according to Abell et al. (1952).

\section{Statistical analyses}

Statistical analysis of the data was done using the SPSS statistical package (SPSS Inc., 1986). Two-way analysis of variance (ANOVA) was used to determine the influence of 


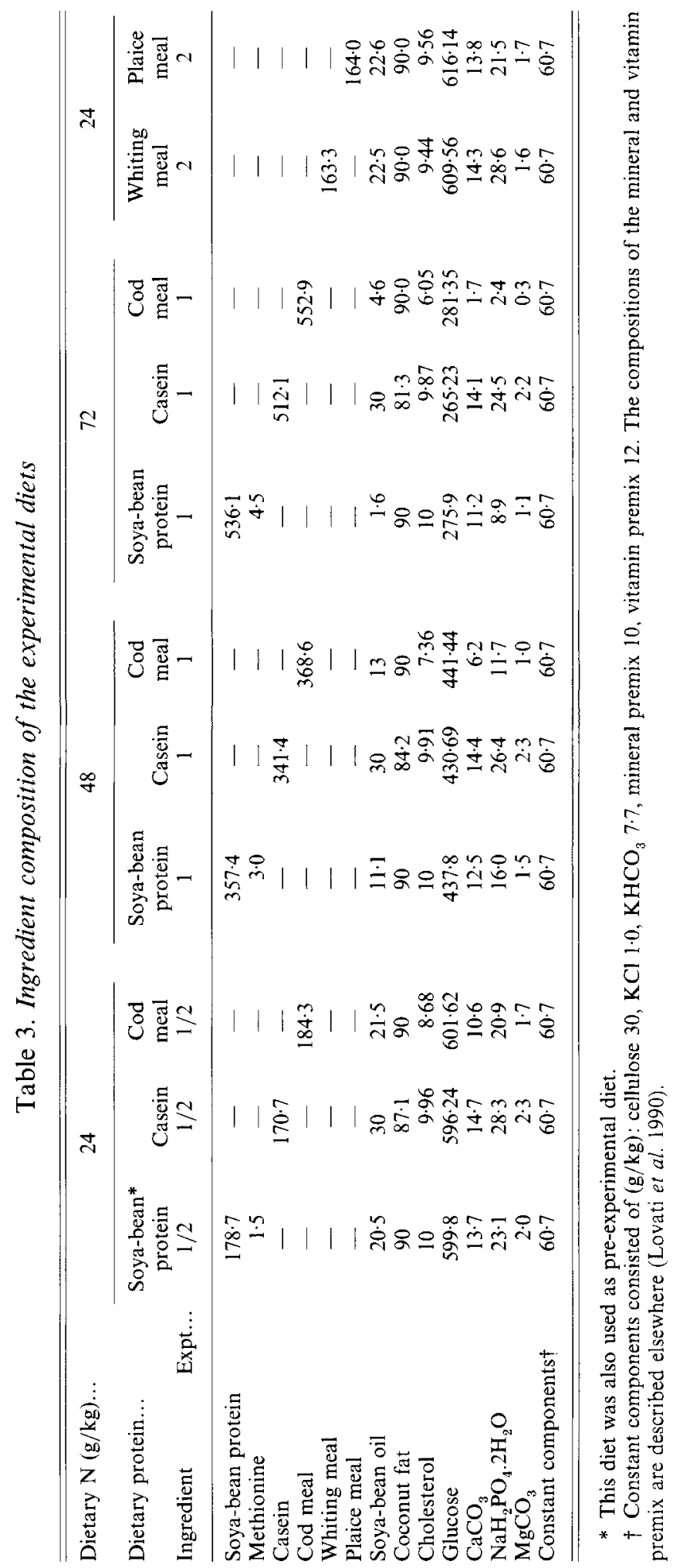




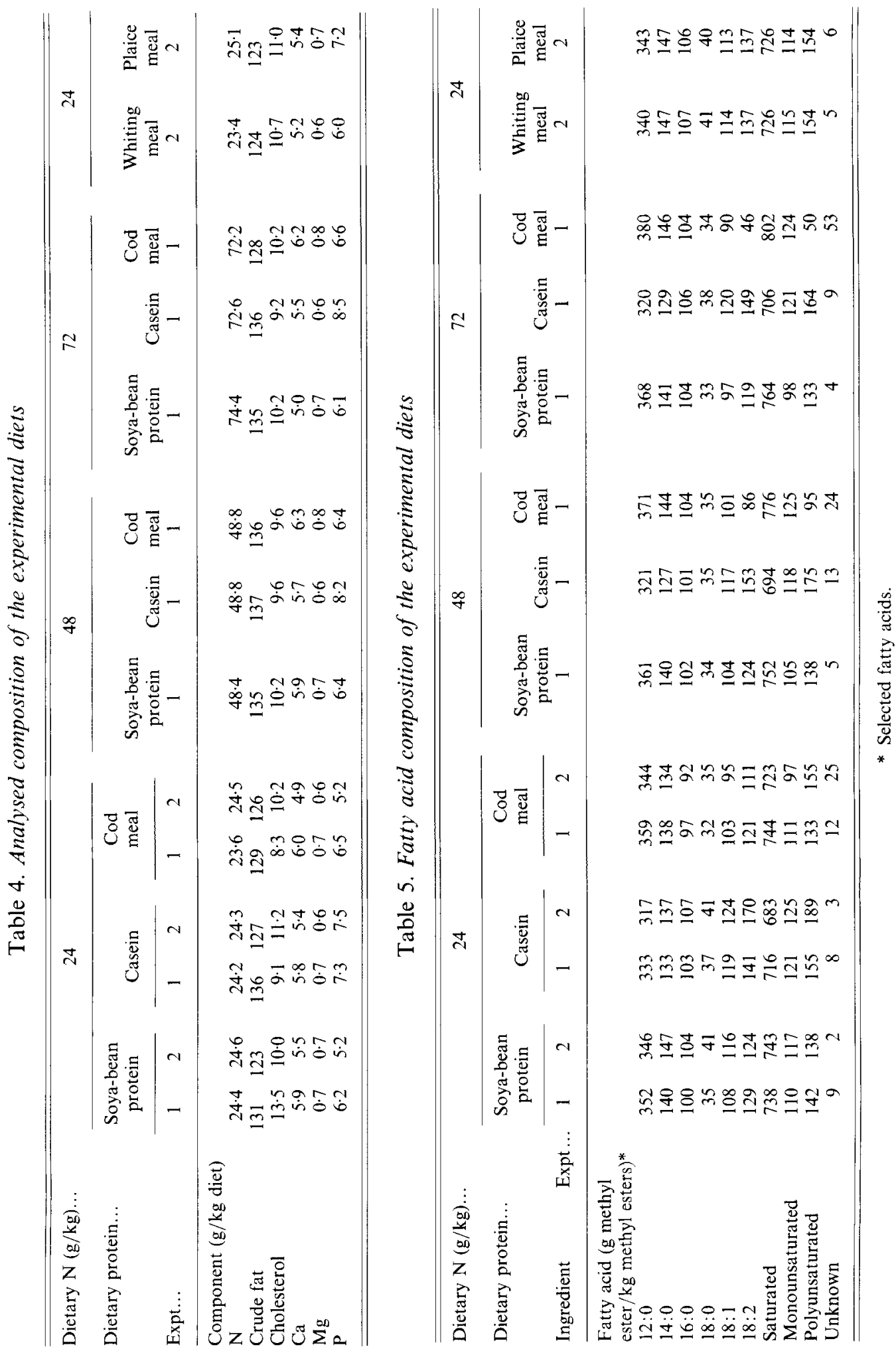


source and level of dietary protein in Expt 1. Group means of dietary groups in Expt 2 were evaluated for statistically significant differences using Duncan's test. The level of significance was pre-set at $P<0.05$.

\section{RESULTS \\ Expt 1}

The type and amount of dietary protein in Expt 1 did not significantly influence body weight (Table 6). Higher intakes of protein at the expense of glucose significantly lowered feed intake. Liver weights fell with increasing amounts of dietary protein in rats fed on either soya-bean protein or cod meal, but not in rats fed on diets containing casein. Soyabean protein produced lower liver weights than did either casein or cod meal.

A decrease in cholesterol concentrations in plasma and liver was observed in rats fed on increasing amounts of either soya-bean protein or cod meal (Table 7). An increase in dietary soya-bean protein concentration from 24 to $72 \mathrm{~g} \mathrm{~N} / \mathrm{kg}$ diet lowered plasma and liver cholesterol concentration by 26 and $75 \%$ respectively. No such dose response was found in rats fed on diets with casein as protein source; the concentration of casein in the diet did not influence plasma and liver cholesterol concentrations. Plasma triacylglycerol levels were significantly reduced when dietary protein level increased, regardless of the source of protein.

\section{Expt 2}

In the second experiment, body weight and feed intake did not differ significantly between the dietary groups (Table 8 ). Soya-bean protein induced significantly lower liver weights than did either casein, cod meal or whiting meal.

Soya-bean protein produced lower group mean plasma cholesterol concentrations than casein, cod meal or whiting meal, but only the difference with whiting meal reached statistical significance (Table 9). Rats given the diet with plaice meal had lower group mean plasma cholesterol concentrations than rats fed on diets containing either casein or whiting meal. As expected, liver cholesterol concentration was significantly higher in rats fed on casein than in those fed on soya-bean protein. Dietary cod meal and whiting meal also caused significantly higher liver cholesterol concentrations than soya-bean protein but produced significantly lower values than casein. Plaice meal in the diet produced liver cholesterol concentrations similar to those induced by soya-bean protein. Plasma triacylglycerol concentrations were not significantly influenced by the type of protein in the diet.

\section{DISCUSSION}

The present studies clearly show that dietary cod meal $v$. either soya-bean protein or casein alters plasma and liver cholesterol concentrations. Cod meal produced lower cholesterol concentrations than casein but higher concentrations than soya-bean protein. The cholesterol-lowering effect of dietary cod meal and soya-bean protein, when compared with casein, was greater with increasing dietary protein levels. In rabbits, cod-fish protein has also been shown to lower serum cholesterol concentrations when compared with casein (Bergeron \& Jacques, 1989). Earlier work carried out with rats has yielded variable results. Cod meal did consistently lower serum cholesterol concentrations when compared with casein, but when compared with soya-bean protein it either lowered or raised serum cholesterol (Jacques et al. 1986; Sugiyama et al. 1986). However, in those studies the experimental diets were not balanced for residual fat and cholesterol in the protein 


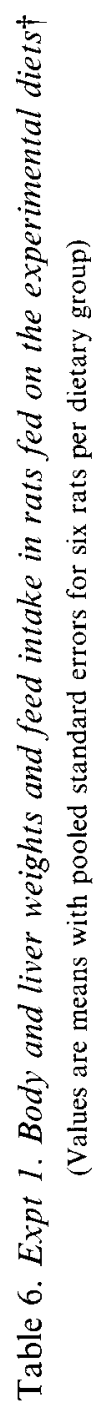

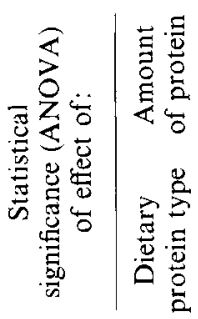

혼

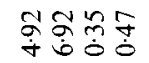

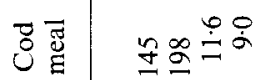

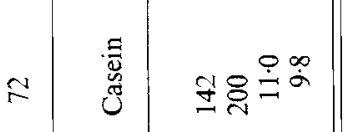

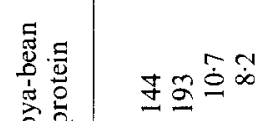

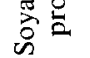

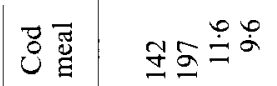

乎

竞离

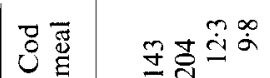

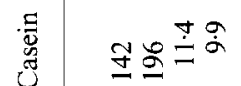

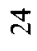

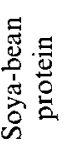

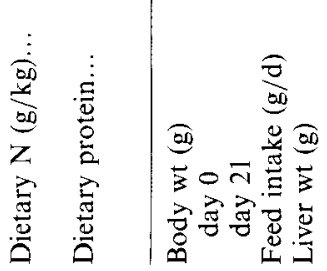

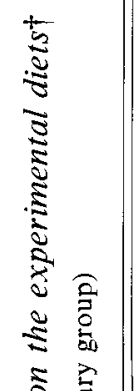

焉

至|

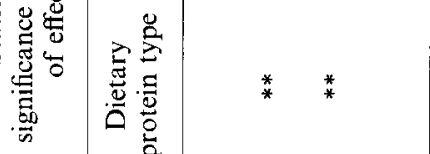

递兽

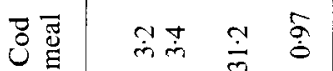

$\therefore$

竞

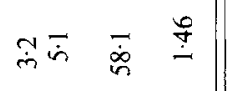

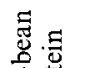

喓

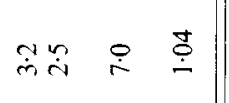

i

递

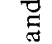

:

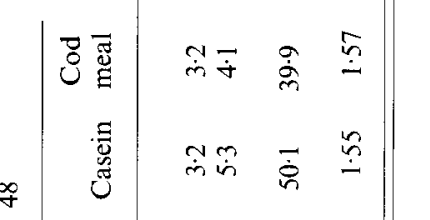

$\stackrel{\infty}{\circ}$

$\stackrel{\infty}{+}$

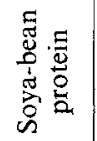

लें $\stackrel{n}{\rightarrow} \stackrel{\circ}{-}$

宮哥

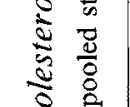

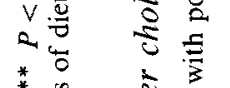

*

空

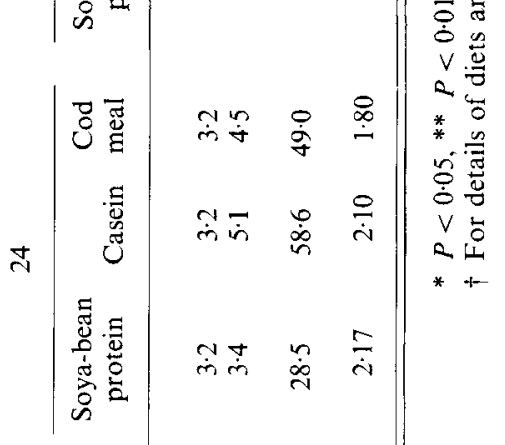

章

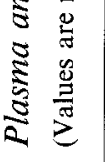

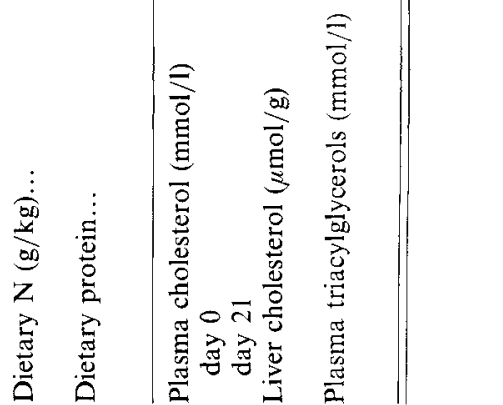



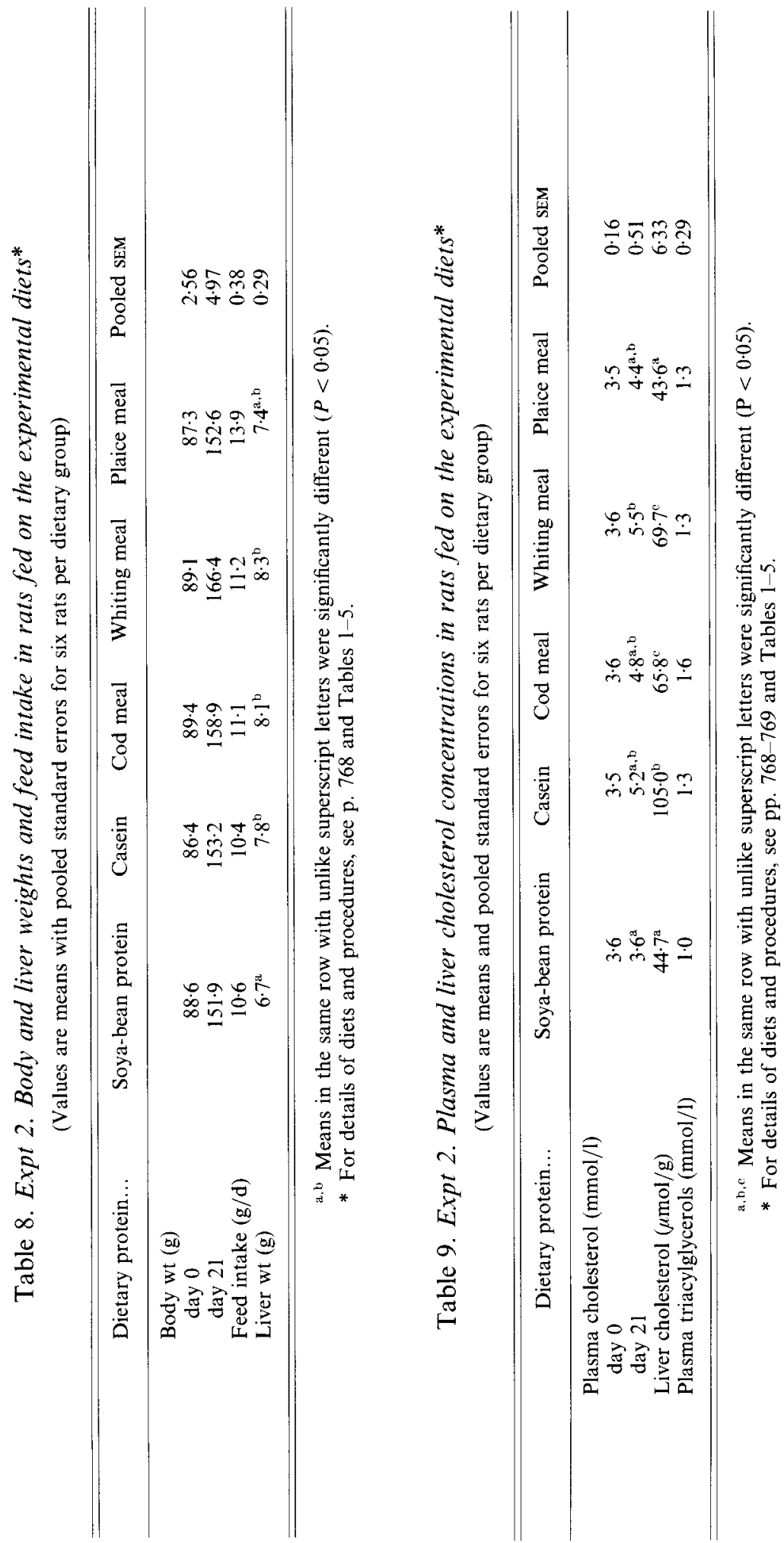
preparations. In the present studies the diets were isonitrogenous and balanced for selected non-protein components of the protein preparations. Table 3 illustrates that this balancing of the diets had been quite successful. Cod meal $v$. soya-bean protein in the diet consistently raised group mean plasma cholesterol concentrations (Tables 7 and 9).

Increasing intakes of soya-bean protein at the expense of glucose lowered plasma and liver cholesterol concentrations, whereas with casein such an effect was not seen (Table 7). This dose-dependent effect of soya-bean protein has been reported earlier (Terpstra et al. $1982 a, b$ ). However, in those studies increasing casein intakes were found to elevate plasma and liver cholesterol concentrations in rats. This discrepancy with the present studies might relate to the use of maize starch instead of glucose as a replacer of protein. The type of carbohydrate in the diet of rats affects plasma and liver cholesterol concentrations, and this effect is influenced by the background composition of the diet (Beynen \& Lemmens, 1987; Meijer \& Beynen, 1988; Herman et al. 1991). A new finding is that increasing intakes of cod meal at the expense of glucose reduced plasma and liver cholesterol concentrations. Thus, the cholesterol-lowering activity of both soya-bean protein and cod meal, when compared with casein, can be enhanced by increasing the proportion of the proteins in the diet.

Whiting meal produced similar plasma cholesterol to casein, but liver cholesterol concentrations were significantly lower in rats fed on whiting meal. This corroborates earlier work (Lapré et al. 1989). In rabbits dietary whiting meal has been shown to elevate serum cholesterol concentrations and to lower liver cholesterol concentrations when compared with casein (Lovati et al. 1990). Thus, in both rabbits and rats whiting meal $v$. casein appears to lower liver cholesterol concentrations. We are not aware of other studies in which serum and liver cholesterol concentrations were determined in rats fed on diets containing plaice meal. Our results indicate that plaice meal has cholesterol-lowering activity when compared with either cod meal or whiting meal, and that this activity is similar to that of soya-bean protein.

The plasma and liver cholesterol concentrations as produced by the dietary protein sources tended to be associated with the amino acid composition of the proteins. In Expt 1 the concentrations of cysteine and glycine in the diet were negatively associated with plasma and liver cholesterol concentrations. In Expt 2 the concentration of methionine in the diet tended to be positively associated with plasma and liver cholesterol concentration. These associations are compatible with results of experiments in which rats were fed on diets containing various amino acid mixtures. In those studies methionine is hypercholesterolaemic and glycine and cysteine are hypocholesterolaemic (Muramatsu \& Sugiyama, 1990). There is evidence that an increase in the glycine:taurine value in conjugated bile acids enhances the hypercholesterolaemic effect of casein $v$. soya-bean protein (Van der Meer \& Beynen, 1987). Since cysteine is a precursor of taurine, high intakes of cysteine might enhance taurine conjugation and, thus, have cholesterol-lowering activity. However, the hypocholesterolaemic properties of glycine cannot be readily explained in the light of formation of bile acid conjugates. Thus, the metabolic basis for the observed relationship between amino acid composition of the dietary proteins and the degree of cholesterolaemia remains obscure.

Animals fed on diets containing soya-bean protein excrete more bile acids and neutral steroids in faeces than their counterparts fed on casein (Beynen, 1990). This effect of protein type probably determines its cholesterolaemic activity. It could be suggested that cod meal and plaice meal enhance faecal excretion of bile acids and neutral steroids when compared with casein in the diet. Further work may test this suggestion.

Xizhong Zhang was supported by a 1988-90 scholarship of Shanxi Provincial Government, The People's Republic of China and by The Netherlands Foundation for Nutrition and 
Health Research. The authors wish to express their appreciation to A. G. Lemmens, J. Ritskes-Hoitinga, F. J. H. Pastoor, G. W. Meijer and H. A. Van Lith for advice concerning chemical and statistical analyses.

\section{REFERENCES}

Abell, L. L., Levy, B. B., Brodie, B. B. \& Kendall, F. E. (1952). A simplified method for the estimation of total cholesterol in serum and demonstration of its specificity. Journal of Biological Chemistry 195, 357-366.

Bergeron, N. \& Jacques, H. (1989). Infiuence of fish protein as compared to casein and soy protein on serum and liver lipids, and serum lipoprotein cholesterol levels in the rabbit. Atherosclerosis 78, 113-121.

Beynen, A. C. (1990). Comparison of the mechanisms proposed to explain the hypocholesterolemic effect of soybean protein versus casein in experimental animals. Journal of Nutritional Science and Vitaminology 35, S87-S93.

Beynen, A. C. \& Lemmens, A. G. (1987). Type of dietary carbohydrate and liver cholesterol in rats. Zeitschrift für Ernährungswissenschaft 26, 158-160.

Carroll, K. K. (1981). Soya protein and atherosclerosis. Journal of the American Oil Chemists' Society 58, $916-919$.

Carroll, K. K. (1982). Hypercholesterolemia and atherosclerosis: effects of dietary protein. Federation Proceedings 41, 2792-2796.

Goulding, N. J., Gibney, M. J., Taylor, T. G. \& Gallagher, P. J. (1983). Reversible hypercholesterolaemia produced by cholesterol-free fish meal protein diets. Atherosclerosis 49, 127-137.

Herman, S., Sediaoetama, A. D., Karyadi, D. \& Beynen, A. C. (1991). Influence of background composition of the diet on the lipemic effect of fish oil versus corn oil in rats. Journal of Nutrition 121, 622-630.

Hoek, A. C., Lemmens, A. G., Mullink, J. W. M. A. \& Beynen, A. C. (1988). Influence of dietary calcium: phosphorus ratio on mineral excretion and nephrocalcinosis in female rats. Journal of Nutrition 118, $1210-1216$.

Iritani, N., Narita, R., Fujita, T. \& Tanaka, T. (1985). Effects of dietary fish protein, soybean protein and casein on cholesterol turnover in rats. Journal of Nutritional Science and Vitaminology 31, 385-392.

Jacques, H., Deshaies, Y. \& Savoie, L. (1986). Relationship between dietary proteins, their in vitro digestion products, and serum cholesterol in rats. Atherosclerosis 61, $89-98$.

Jacques, H., Deshaies, Y. \& Savoie, L. (1987). Relationship between dietary tyrosine and plasma cholesterol in rats. Canadian Journal of Physiology and Pharmacology 66, 1023-1027.

Joslyn, M. A. (1970). Methods in Food Analysis, 2nd ed. New York, NY: Academic Press.

Kritchevsky, D. (1979). Vegetable protein and atherosclerosis. Journal of the American Oil Chemists' Society 56, $135-140$

Kritchevsky, D., Tepper, S. A., Czarnecki, S. K. \& Klurfeld, D. M. (1982). Atherogenicity of animal and vegetable protein: influence of the lysine to arginine ratio. Atherosclerosis 41, 429-431.

Lapré, J. A., West, C. E., Lovati, M. R., Sirtori, C. R. \& Beynen, A. C. (1989). Dietary animal proteins and cholesterol metabolism in rats. International Journal for Vitamin and Nutrition Research 59, 93-100.

Lovati, M. R., West, C. E., Sirtori, C. R. \& Beynen, A. C. (1990). Dietary animal proteins and cholesterol metabolism in rabbits. British Journal of Nutrition 64, 473-485.

Meijer, G. W. \& Beynen, A.C. (1988). Interrelated effects of the type of dietary fat and carbohydrate on cholesterol metabolism in rats. International Journal for Vitamin and Nutrition Research 58, 241-245.

Metcalfe, L. D., Schmitz, A. A. \& Pelka, J. R. (1966). Rapid preparation of fatty acid esters from lipids for gas chromatography analysis. Analytical Chemistry 18, 514-515.

Moore, S. (1963). On the determination of cystine as cysteic acid. Journal of Biological Chemistry 238, 235-237.

Muramatsu, K. \& Sugiyama, K. (1990). Relationship between amino acid composition of dietary protein and plasma cholesterol level in rats. Monographs on Atherosclerosis 16, 97-109.

Nordby, H. E. \& Nagy, S. (1973). An evaluation of recent gas-liquid chromatographic liquid phases for resolution of acetylated plant sterols. Journal of Chromatography 75, 187-193.

Peifer, J. J., Janssen, F., Muesing, R. \& Lundberg, W. O. (1961). The lipid depressant activities of whole fish and their component oils. Journal of the American Oil Chemists' Society 39, 292-296.

Slump, P. \& Bos, K. D. (1985). Determination of methionine in feed concentrates. Poultry Science 64, 705-707.

SPSS Inc. (1986). SPSSX User's Guide, 2nd ed. Chicago, IL: SPSS Inc.

Sugano, M., Ishiwaki, N. \& Nakashima, K. (1984). Dietary protein-dependent modification of serum cholesterol level in rats: significance of the arginine/lysine ratio. Annals of Nutrition and Metabolism 28, 192-199.

Sugiyama, K., Ohkawa, S. \& Muramatsu, K. (1986). Relationship between amino acid composition of diet and plasma cholesterol level in growing rats fed a high cholesterol diet. Journal of Nutritional Science and Vitaminology 32, 413-423.

Taussky, H. H. \& Shorr, E. (1953). A microcolorimetric method for the determination of inorganic phosphorus. Journal of Biological Chemistry 202, 675-685.

Terpstra, A. H. M., Van Tintelen, G. \& West, C. E. (1982a). The effect of semipurified diets containing different proportions of either casein or soybean protein on the concentration of cholesterol in whole serum, serum lipoproteins and liver in male and female rats. Atherosclerosis 42, 85-95. 
Terpstra, A. H. M., Van Tintelen, G. \& West, C. E. (1982b). The hypocholesterolemic effect of dietary soy protein in rats. Journal of Nutrition 112, 810-817.

Van der Meer, R. \& Beynen, A. C. (1987). Species-dependent responsiveness of serum cholesterol to dietary proteins. Journal of the American Oil Chemists' Society 64, 1172-1177.

Wexler, B. C. (1983). Low protein fish vs low protein animal diet enhances the propensity for stroke in strokeprone/SHR rats. Stroke 14, 585-590.

Zhang, X. \& Beynen, A.C. (1990). Dietary fish proteins and cholesterol metabolism. Monographs on Atherosclerosis 16, 148-152. 